\title{
INSERTION OF SUSTAINABILITY CONCEPTS IN THE MAINTENANCE STRATEGIES TO ACHIEVE SUSTAINABLE MANUFACTURING
}

\author{
Renan Stenico de Campos \\ Universidade Metodista de Piracicaba (UNIMEP), Brazil \\ E-mail: renanstenico@hotmail.com \\ Alexandre Tadeu Simon \\ Universidade Metodista de Piracicaba (UNIMEP), Brazil \\ E-mail: alexandre.simon@unimep.br
}

Submission: $12 / 18 / 2018$

Revision: $2 / 8 / 2019$

Accept: 2/27/2019

\section{ABSTRACT}

Companies adopt sustainable practices in order to improve the economic, environmental and social performance of their operations. This fact does not occur with the same intensity in maintenance operations. By adopting sustainable practices during the implementation of maintenance strategies, there will be mitigation of industrial maintenance impacts on sustainability. However, there are few studies on the integration of sustainability in maintenance activities and few companies adopt sustainable maintenance due to lack of knowledge of the subject and its benefits. This paper aims to show how the concepts of sustainability are being inserted in the maintenance strategies. For this purpose, a literature review and a systematic literature review were performed. It was verified that the concepts of sustainability are integrated into maintenance strategies by means of sustainable criteria, with emphasis on lost production cost, spare parts cost and expenditures associated with energy consumption and greenhouse gas emissions (economic dimension), on pollutant emission due to energy consumption during machining/manufacturing (environmental dimension) and on health and safety at work (social dimension). This paper contributes to the dissemination of the theme and motivates the companies to implement sustainable maintenance. 
INDEPENDENT JOURNAL OF MANAGEMENT \& PRODUCTION (IJM\&P)

http://www.ijmp.jor.br

v. 10, n. 6, November - December 2019

ISSN: 2236-269X

DOI: 10.14807/ijmp.v10i6.939

Keywords: Sustainability; Maintenance Strategies; Sustainable Maintenance

\section{INTRODUCTION}

Sustainability has been used in competitive strategies of many companies to make them different in their field. Organizations adopting sustainable practices are able to achieve better quality in their products and services, greater market share and increased profits (NAMBIAR, 2010). However, it should be emphasized that sustainable practices are not limited only to achieving better economic performance, but to integrating other performances that go beyond this perspective, such as the environmental and social (ASHLEY, 2005).

Sustainable manufacturing initiatives have been integrated into decisionmaking processes in various industrial and government projects (O'CONNOR; SPASH, 1999). Companies using the concept of sustainable manufacturing consider economic, environmental and social issues at every stage of the product life cycle, from the design to the delivery for end user (NEZAMI; YILDIRIM, 2011).

Regarding economic issues, for example, the costs of consumed energy and generated waste have an impact on the profitability of production systems (GUTOWSKI et al., 2005) and reducing these costs not only results in economic benefits, but also environmental benefits (DIMITROFF-REGATSCHNIG; SCHNITZER, 1998).

Regarding environmental issues, the best performance is characterized by the reduction of energy consumption, minimization of toxic waste generated, use of natural resources efficiently and adoption of evaluation methods for the product life cycle (PUSAVEC et al., 2010). Regarding social issues, the programs focused on health, safety and employee qualification (JASIULEWICZ-KACZMAREK et al., 2013b) stand out.

Although there is an emphasis on the adoption of sustainability concepts in the design, manufacturing, use and reuse of products (JAYAL et al., 2010), maintenance operations are already beginning to be recognized as an essential part of the quest for a sustainable condition (SARI et al., 2015).

Industrial maintenance is considered a key support area for sustainable manufacturing, contributing to the reduction of breakdowns, energy waste and internal 
DOI: 10.14807/ijmp.v10i6.939

and external costs associated with the production line (JASIULEWICZ-KACZMAREK, 2013a; IUNG; LEVRAT, 2014). This trend can be confirmed by the emergence of the concept of sustainable maintenance that, through maintenance strategies, seeks a continuous improvement of maintenance actions in the economic, environmental and social dimensions (JASIULEWICZ-KACZMAREK, 2013a; SAVINO et al., 2015).

Failure to adopt sustainability concepts in maintenance can mean higher repair costs, increased equipment energy consumption and increased work-related accidents (YAN; HUA, 2010; RADHOUI et al., 2012; JASIULEWICZ-KACZMAREK et al., 2013b).

Due to the lack of knowledge about sustainable maintenance and its benefits, very few companies adopt the concept (FRANCIOSI et al., 2017). This can also be confirmed by the low number of published works on the integration of sustainability in maintenance activities (PIRES et al., 2015).

The objective of this article is to show how sustainability concepts are being inserted in maintenance strategies aiming to contribute to the dissemination of the theme and motivate companies to implement sustainable maintenance.

The article is structured in five sections, including this introduction that presents the research objective; following are the relevant concepts and theories; the research method adopted; the analysis and discussion of the results obtained; and, finally, the final considerations.

\section{LITERATURE REVIEW}

This section presents a literature review on sustainability, maintenance strategies and sustainable maintenance.

\subsection{Sustainability}

Sustainability has been discussed by researchers and entrepreneurs for several years, beginning with the discussions between 1950 and 1960 on environmental issues at various global conferences and events, to more recent events such as the United Nations (UN) decision to adopt a set of new sustainable development goals in 2015, also considering social and economic issues (GUDMUNDSSON et al., 2015). 
INDEPENDENT JOURNAL OF MANAGEMENT \& PRODUCTION (IJM\&P)

http://Www.ijmp.jor.br

v. 10, n. 6, November - December 2019

ISSN: 2236-269X

DOI: 10.14807/ijmp.v10i6.939

Literature presents several definitions for sustainable development, with rumors that there are more than two hundred definitions for the term. Despite this, a widely used concept was created in 1987 by the World Commission on Environment and Development (WCED) and accepted by the UN at the Earth Summit in 1982, regarded as development that meets the current needs, not compromising the ability of future generations to meet their own needs (BRUNDTLAND, 1987).

The definition of WCED does not distinguish sustainable development from sustainability. Briefly, sustainable development can be described as the process by which, over time, people achieve sustainability. Sustainability is the goal to be achieved so that the environment presents conditions to sustain life on Earth (PARKIN, 2000).

By bringing the premises of sustainable development to the business environment, organizations can be considered sustainable if they can manage their activities and achieve good results in three dimensions that make up sustainability: economic, environmental and social. This sustainable goal can be represented with the concept of triple bottom line or 3P's (profit, people and planet) formulated by John Elkington in 1998, represented in Figure 1 (ELKINGTON, 1998).

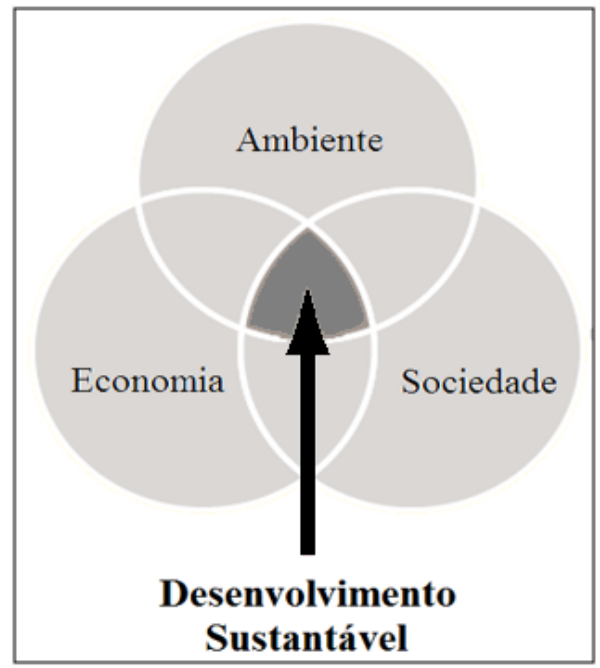

Figure 1: Concept of triple bottom line Source: Adapted from Elkington (1998)

Sustainability is integrated into production systems, considering economic, environmental and social issues at every stage of a product's life cycle from creation to delivery to the end user (NEZAMI; YILDIRIM, 2011). Economic issues focus on actions that reduce production costs by managing productivity, spending, and investments. Environmental issues focus on energy efficiency and reduction of 
DOI: 10.14807/ijmp.v10i6.939

pollutant emissions, consumption of hazardous materials, frequency of environmental accidents and other impacts on the environment. On the other hand, social issues focus on to improve working conditions, health and safety of workers and labor issues (JAMALI, 2006).

\subsection{Maintenance Strategies}

Equipment failures can cause catastrophic effects in a production system, resulting in higher repair costs, reduced quality of the final product, as well as causing total shutdown of the production line. Mitigation of these effects is achieved through an appropriate strategy for maintenance actions (SHARMA et al., 2005).

The maintenance strategy can be described as a systematic approach (stepby-step procedure) to keep equipment and installations in operation, involving guidelines for investigation, identification and performance of repairs (KELLY, 1997).

The maintenance strategy characterizes which events (including failure type, condition and periodicity) trigger the maintenance (inspection, repair or replacement) tasks to be performed (PINJALA, 2008). According to Marquez and Gupta (2006), maintenance strategies are procedures used to transform business objectives into maintenance objectives.

Most used maintenance strategies found in literature are: i) corrective maintenance, ii) preventive maintenance, iii) condition-based maintenance, iv) total productive maintenance and $v$ ) reliability centered maintenance.

Corrective maintenance $(\mathrm{CM})$ is the maintenance strategy used when there is a random failure in a component. Generally, this strategy is implemented in companies with large profit margins (CHITRA, 2003; WANG et al., 2007).

Preventive maintenance $(P M)$ is the maintenance strategy that seeks to improve the service life of the equipment, preventing them from excessive weakening and depreciation. This type of maintenance encompasses the activities of adjustment, repairs, replacements, lubrication, cleaning and extension of equipment service life (WIREMAN, 1990).

The PM makes use of the periodic inspection at predetermined times (age or calendar time), without considering the condition of the machine. Inadequate inspection 
DOI: 10.14807/ijmp.v10i6.939

intervals and unpredictability of maintenance generate unnecessary costs for the company (AL-NAJJAR; ALSYOUF, 2003).

Condition-based maintenance (CBM), also known as predictive maintenance (PdM), is implemented by many companies today. CBM uses data collected through vibration monitoring, ultrasonic testing, and lubrication analysis, among others, to investigate the conditions of the elements that make up the equipment. If the monitored value exceeds the normal level, the component is replaced or repaired.

Generally, CBM implementation costs are high because of the need for specialized labor force and specific equipment for monitoring. However, the correct application and management of CBM can generate considerable reductions in total cost of production, reducing it from 5 to 45\% (GRALL et al., 2002; AL-NAJJAR; ALSYOUF, 2003; SHARMA et al., 2005; ZHANG, 2013).

Total productive maintenance (TPM) is a Japanese maintenance strategy that focuses on the maximum efficiency of the production system. This maximum efficiency is achieved through: improvement of the production system (with the reduction of downtime and preparation of the machines, keeping the system speed constant); improving the quality of products and services; elimination of failures due to breaks and the constant improvement of employees' skills and knowledge (WILLMOTT; MCCARTH, 2000).

Reliability centred maintenance ( $R C M)$ is a logical and systematic maintenance strategy used to determine which maintenance actions should be performed on the equipment, taking into account the operational, environmental and safety consequences of each failure found (MOUBRAY, 2000). The success of this strategy stems from the availability of fault data, analysis methods and operational experience to achieve its goal (GANDHARE; AKARTE, 2012). Therefore, one of the difficulties encountered when executing the RCM is the unavailability of fault data in the analyzed system (SHARMA et al., 2005).

\subsection{Sustainable Maintenance}

Sustainable maintenance emerges as a new challenge for companies using the sustainability strategy, defined as actions or maintenance tasks that promote a balance between the economic, environmental and social dimensions. Therefore, sustainable maintenance does not only focus on financial terms, such as repairing cost 
and materials consumed cost, but also in environmental terms - such as greenhouse gas (GHG) emissions and energy consumption - and social issues related to worker's health and safety (JASIULEWICZ-KACZMAREK, 2013a). The studies of Nezami and Yildirim (2011), Jasiulewicz-Kaczmarek (2013b), Saniuk et al. (2015), Sari et al. (2015), Amrina and Aridharma (2016) and Franciosi et al. (2017) also discuss the concept of sustainable maintenance, however, superficially.

In order for maintenance actions to promote a balance between economic, environmental and social dimensions, sustainability concepts must first be approached in maintenance strategies, so as to have better control of maintenance costs, better quality of products and services, decreasing of environmental impacts resulting from maintenance actions and contribute to the economic well-being, health, safety and education of employees (HENNEQUIN; RESTREPO, 2016).

In addition to presenting the concept of sustainable maintenance, JasiulewiczKaczmarek (2013a) shows the internal and external benefits that the company acquires when practicing sustainable maintenance. Examples of these benefits are contained in Table 1.

Table 1: Internal and external benefits when applying sustainable maintenance

\begin{tabular}{|c|c|c|c|}
\hline Benefits & Economic & Environmental & Social \\
\hline Internal & $\begin{array}{l}\text { - Limitation of } \\
\text { environmental charges; } \\
\text { - Limitation of stock of } \\
\text { materials; } \\
\text { - Product cost per unit } \\
\text { limit }\end{array}$ & $\begin{array}{l}\text { - Limitation of the } \\
\text { amount of waste } \\
\text { generated; } \\
\text { - Limitation of energy } \\
\text { consumption }\end{array}$ & $\begin{array}{l}\text { - Improved safety of } \\
\text { operators and technical } \\
\text { personnel; } \\
\text { - Reduction of the } \\
\text { number of accidents at } \\
\text { work }\end{array}$ \\
\hline External & $\begin{array}{l}\text { - Limitation of risk of } \\
\text { serious damage; } \\
\text { - Limitation of fines } \\
\text { resulting from failures; } \\
\text { - Increasing the } \\
\text { competitiveness of an } \\
\text { organization }\end{array}$ & $\begin{array}{l}\text { - Elimination or } \\
\text { reduction of fines } \\
\text { resulting from wrong } \\
\text { practices; } \\
\text { - Reduction of } \\
\text { disturbances and } \\
\text { nonconformities for local } \\
\text { societies; } \\
\text { - Reduction in the use } \\
\text { of non-renewable } \\
\text { resources }\end{array}$ & $\begin{array}{l}\text { - Positive image of the } \\
\text { company in the context of } \\
\text { safety and health }\end{array}$ \\
\hline
\end{tabular}

Source: Jasiulewicz-Kaczmarek (2013a)

According to Ighravwe et al. (2017), organizations that intend to design a sustainable maintenance plan for their facilities, with the objective of improving maintenance actions in the manufacturing system, must consider four decisive factors: i) selection of the maintenance strategy, ii) training of employees involved in maintenance; iii) control of production equipment to generate less waste; and iv) 
INDEPENDENT JOURNAL OF MANAGEMENT \& PRODUCTION (IJM\&P)

http://Www.ijmp.jor.br

v. 10, n. 6, November-December 2019

ISSN: 2236-269X

DOI: 10.14807/ijmp.v10i6.939

optimization of the materials consumed during the maintenance actions, represented in Figure 2.

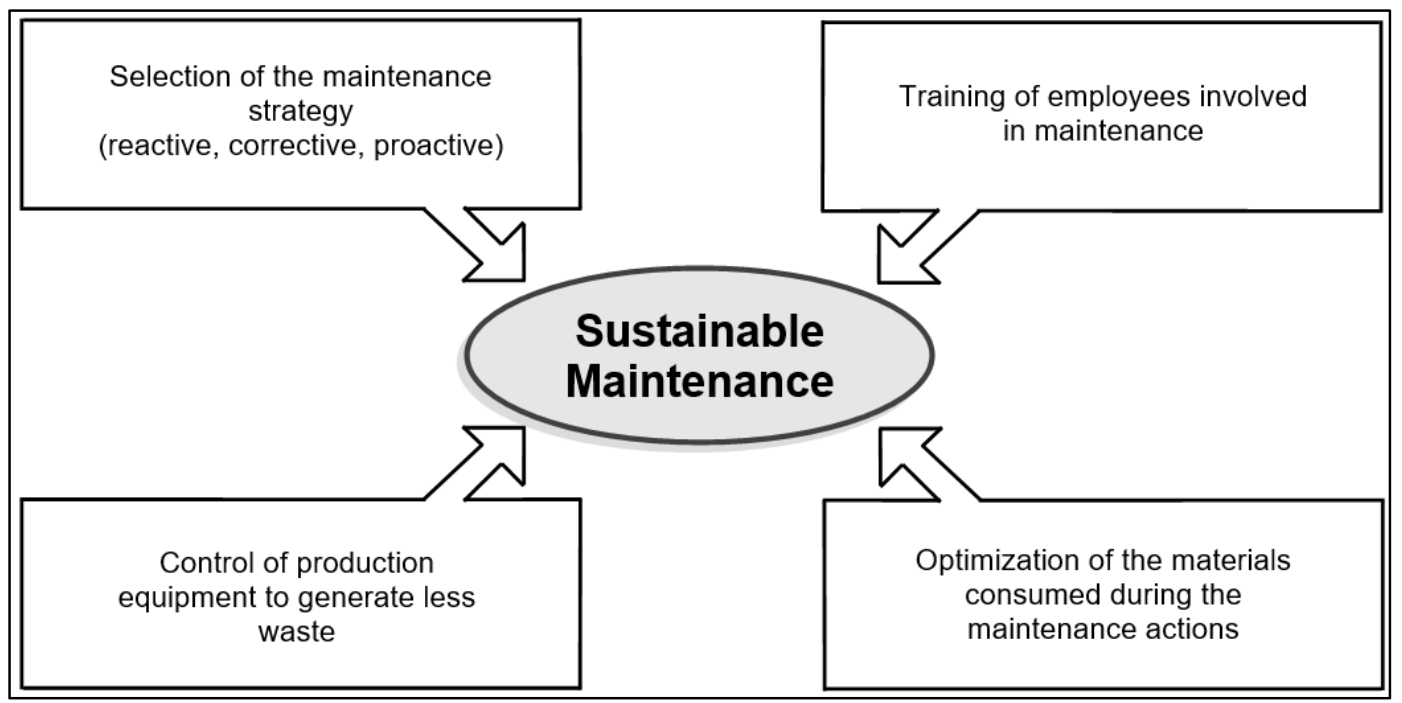

Figure 2: Key factors for the implementation of sustainable maintenance Source: adapted from Ighravwe et al. (2017)

The selection of the appropriate maintenance strategy minimizes the probability of failures in the production system and its consequences related to safety, economy and environment (KHAN; HADDARA, 2003). The training given to the employees involved in the maintenance allows sustainable practices to be taken, minimizing the sector's impacts on sustainability.

Control of production equipment is essential for the reduction of environmental pollution, noise from industrial activities, and liquids and solids generated. The optimization of the materials consumed during maintenance actions is improved when employees are more aware of sustainable practices (IGHRAVWE et al., 2017).

\section{RESEARCH METHOD}

In order to identify and select the main works that consider the concepts of sustainability in the maintenance strategies, the methodology of systematic literature review of Levy and Ellis (2006) was used. The method relies on three steps: Input, Processing and Output, as shown in Figure 3. 
ISSN: 2236-269X

DOI: 10.14807/ijmp.v10i6.939

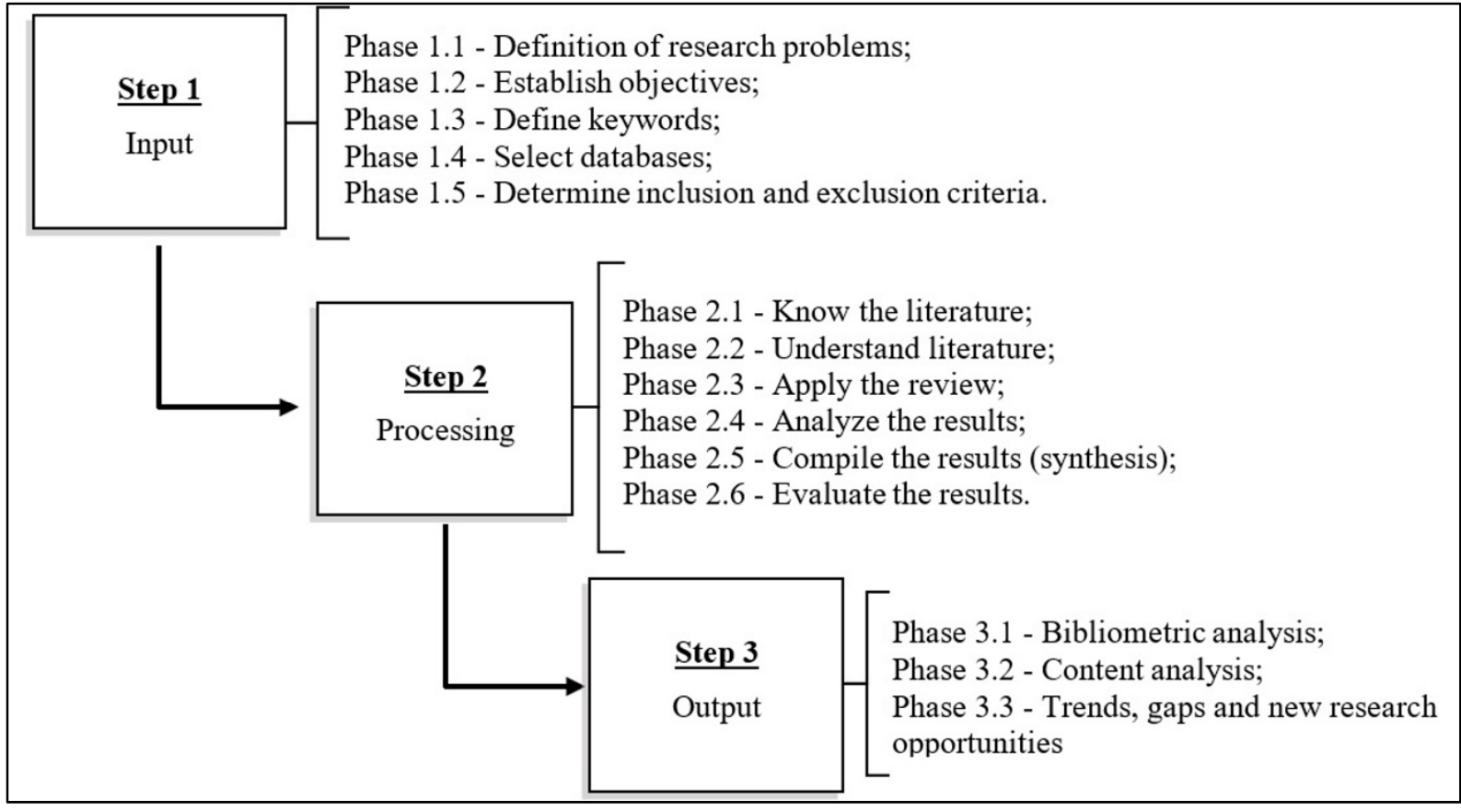

Figure 3: Steps of systematic literature review

Source: adapted from Levy and Ellis (2006)

In Step 1, the research problem (Phase 1.1) and the objective of the work (Phase 1.2) were defined, such phases described in the introductory section of the article. In Phase 1.3, the keywords or expressions to be used in the academic databases were defined to find the scientific papers aligned with the study objective (Table 2).

Table 2: Definition of search keywords

\begin{tabular}{c}
\hline Definition of the keywords \\
\hline ("Sustainability" OR "Sustainable Development" OR “Triple Bottom Line") \\
AND \\
("Maintenance" OR "Maintenance Strategy" OR "Maintenance Management") \\
AND \\
("Industr" OR "Compan" OR "Machin")
\end{tabular}

Source: Authors

In Phase 1.4, three international databases were selected to find the scientific papers: Science Direct, Scopus and Web of Science. The databases were selected for presenting the largest number of papers published in the area, allowing the use of other software during the screening process and providing more details about the selected papers. 
DOI: 10.14807/ijmp.v10i6.939

As inclusion and exclusion criteria (Phase 1.5), only articles published in journals and in annals of international congresses were considered for the availability of access to the content of these documents. In this way, 2266 articles were found in the three searched databases containing the combinations of terms used in the title, and/or in the abstract and/or in the keywords.

In Step 2, the preliminary criteria defined in the previous step are processed through six phases: know the literature (Phase 2.1), understand the literature (Phase 2.2), apply the review (Phase 2.3), analyze the results (Phase 2.4), compile the results (Phase 2.5) and evaluate the results (Phase 2.6); in a cyclical way, to select the relevant papers and include other documents.

After reading the titles, abstracts and keywords, 79 articles were selected in a first screening: studies involving the concept of sustainability and maintenance in the industrial area. The excluded articles addressed the concepts in the field of civil construction, transportation, agriculture, medicine and others.

After a complete reading of the 79 articles (second screening), it was verified that only 21 documents contemplated the insertion of the concepts of sustainability in the maintenance strategies. Through the snowballing method, technique that inserts relevant works cited in the references of the sample obtained by the systematic literature review, 3 other documents were included. The small number of articles selected shows that the subject is still little studied. The bibliographic portfolio of selected articles is illustrated in Table 3.

In Step 3, the presentation and discussion of the data obtained with the systematic literature review is performed through three phases. The bibliometric analysis (Phase 3.1) quantitatively evaluates the selected articles from the year of publication, authors and journals that publish in the area and methodologies applied. The content analysis (Phase 3.2) describes and interprets the relevant information of the consulted works, in order to understand how the concepts of sustainability are being inserted into maintenance strategies. Phase 3.3 presents the trends, gaps and new research opportunities in the field. The three phases are shown in the sequence.

\section{ANALYSIS AND DISCUSSION OF RESULTS}


INDEPENDENT JOURNAL OF MANAGEMENT \& PRODUCTION (IJM\&P)

http://Www.ijmp.jor.br

v. 10, n. 6, November-December 2019

ISSN: 2236-269X

DOI: 10.14807/ijmp.v10i6.939

This section presents the bibliometric analysis and the content analysis of the selected papers, as well as the discussion about trends, gaps and new research opportunities.

\subsection{Bibliometric Analysis}

The bibliometric analysis aims to show, through quantitative evaluations, the number of publications that have occurred over the years, the most cited authors, the main journals that publish the studies related to the subjects researched and the subjects most discussed in the articles.

Table 3: Selected articles that make up the bibliographic portfolio

\begin{tabular}{|c|c|c|c|c|}
\hline $\mathbf{N}^{\circ}$ & Authors & Title & $\begin{array}{c}\text { Year of } \\
\text { publication }\end{array}$ & $\begin{array}{l}\mathrm{N}^{\circ} \text { of } \\
\text { citation }\end{array}$ \\
\hline 1 & $\begin{array}{l}\text { Jasiulewicz- } \\
\text { Kaczmarek }\end{array}$ & $\begin{array}{c}\text { The role of ergonomics in implementation of the } \\
\text { social aspect of sustainability, illustrated with the } \\
\text { example of maintenance }\end{array}$ & 2013 & 19 \\
\hline 2 & $\begin{array}{l}\text { Nezami } \\
\text { and Yildirim }\end{array}$ & $\begin{array}{l}\text { A sustainability approach for selecting maintenance } \\
\text { strategy }\end{array}$ & 2013 & 19 \\
\hline 3 & Saniuk et al. & $\begin{array}{l}\text { Environmental favourable foundries through } \\
\text { maintenance activities }\end{array}$ & 2015 & 13 \\
\hline 4 & Sari et al. & $\begin{array}{l}\text { Sustainable maintenance performance measures: } \\
\text { a pilot survey in Malaysian automotive companies }\end{array}$ & 2015 & 13 \\
\hline 5 & $\begin{array}{l}\text { Jasiulewicz- } \\
\text { Kaczmarek }\end{array}$ & $\begin{array}{l}\text { Integrating lean and green paradigms in } \\
\text { maintenance management }\end{array}$ & 2014 & 13 \\
\hline 6 & $\begin{array}{l}\text { Jasiulewicz- } \\
\text { Kaczmarek }\end{array}$ & $\begin{array}{l}\text { Practical aspects of the application of RCM to select } \\
\text { optimal maintenance policy of the production line }\end{array}$ & 2015 & 12 \\
\hline 7 & Yan and Hua & Energy consumption modeling for machine tools & 2010 & 12 \\
\hline 8 & $\begin{array}{l}\text { Jasiulewicz- } \\
\text { Kaczmarek }\end{array}$ & $\begin{array}{c}\text { The role and contribution of maintenance in } \\
\text { sustainable manufacturing }\end{array}$ & 2013 & 9 \\
\hline 9 & Savino et al. & $\begin{array}{c}\text { Investigating the impact of social sustainability } \\
\text { within maintenance operations: an action research } \\
\text { in heavy industry }\end{array}$ & 2015 & 6 \\
\hline 10 & $\begin{array}{l}\text { Nezami } \\
\text { and Yildirim }\end{array}$ & $\begin{array}{c}\text { A framework for a fuzzy sustainable maintenance } \\
\text { strategy selection problem }\end{array}$ & 2011 & 6 \\
\hline 11 & Sénéchal & $\begin{array}{l}\text { Research directions for integrating the triple bottom } \\
\text { line in maintenance dashboards }\end{array}$ & 2017 & 4 \\
\hline 12 & Jiang et al. & $\begin{array}{l}\text { Development and optimization of a condition-based } \\
\text { maintenance policy with sustainability requirements } \\
\text { for production system }\end{array}$ & 2018 & 2 \\
\hline 13 & Kumar et al. & $\begin{array}{c}\text { A big data driven sustainable manufacturing } \\
\text { framework for condition-based maintenance } \\
\text { prediction }\end{array}$ & 2018 & 2 \\
\hline 14 & $\begin{array}{l}\text { Franciosi et } \\
\text { al. }\end{array}$ & $\begin{array}{c}\text { Sustainable maintenance: a periodic preventive } \\
\text { maintenance model with sustainable spare parts } \\
\text { management }\end{array}$ & 2017 & 2 \\
\hline 15 & $\begin{array}{l}\text { Amrina and } \\
\text { Aridharma }\end{array}$ & $\begin{array}{l}\text { Sustainable maintenance performance evaluation } \\
\text { model for cement industry }\end{array}$ & 2016 & 2 \\
\hline
\end{tabular}


INDEPENDENT JOURNAL OF MANAGEMENT \& PRODUCTION (IJM\&P)

http://Www.ijmp.jor.br

v. 10, n. 6, November-December 2019

ISSN: 2236-269X

DOI: 10.14807/ijmp.v10i6.939

\begin{tabular}{|c|c|c|c|c|}
\hline 16 & Hoang et al. & $\begin{array}{c}\text { Investigation on the use of energy efficiency for } \\
\text { condition-based maintenance decision-making }\end{array}$ & 2016 & 2 \\
\hline 17 & Xia et al. & $\begin{array}{c}\text { Energy-oriented maintenance decision-making for } \\
\text { sustainable manufacturing based on energy saving } \\
\text { window }\end{array}$ & 2018 & 1 \\
\hline 18 & Radhoui et al. & $\begin{array}{c}\text { Preventive maintenance policy for multi-component } \\
\text { systems subject to random environmental damage } \\
\text { generation }\end{array}$ & 2012 & 1 \\
\hline 20 & Do et al. & $\begin{array}{c}\text { Energy efficiency for condition-based maintenance } \\
\text { decision-making: application to a manufacturing } \\
\text { platform }\end{array}$ & 2018 & 0 \\
\hline 21 & $\begin{array}{c}\text { Improving sustainability performance of heating } \\
\text { facilities in a central boiler room by condition-based } \\
\text { al. }\end{array}$ & $\begin{array}{c}\text { Concept of the FMEA method-based model } \\
\text { supporting proactive and preventive maintenance } \\
\text { activities }\end{array}$ & 2018 & 0 \\
\hline 23 & Sénéchal & $\begin{array}{c}\text { Performance indicators nomenclatures for decision } \\
\text { making in sustainable conditions based } \\
\text { maintenance }\end{array}$ & 2018 & 0 \\
\hline 24 & Pires et al. & $\begin{array}{c}\text { Industrial maintenance for sustainable performance: } \\
\text { a systematic literature review }\end{array}$ & 2015 & 0 \\
\hline
\end{tabular}

Source: Authors

All 24 articles with their respective year of publication and other relevant information were cataloged according to Table 3. In Figure 4, the publications involving the insertion of sustainability concepts in the maintenance strategies occurred between 2010 and 2019, with more publications in 2018. It is verified that there are few studies in this area of research, which makes it difficult to apply the concept of sustainable maintenance in the industrial area.

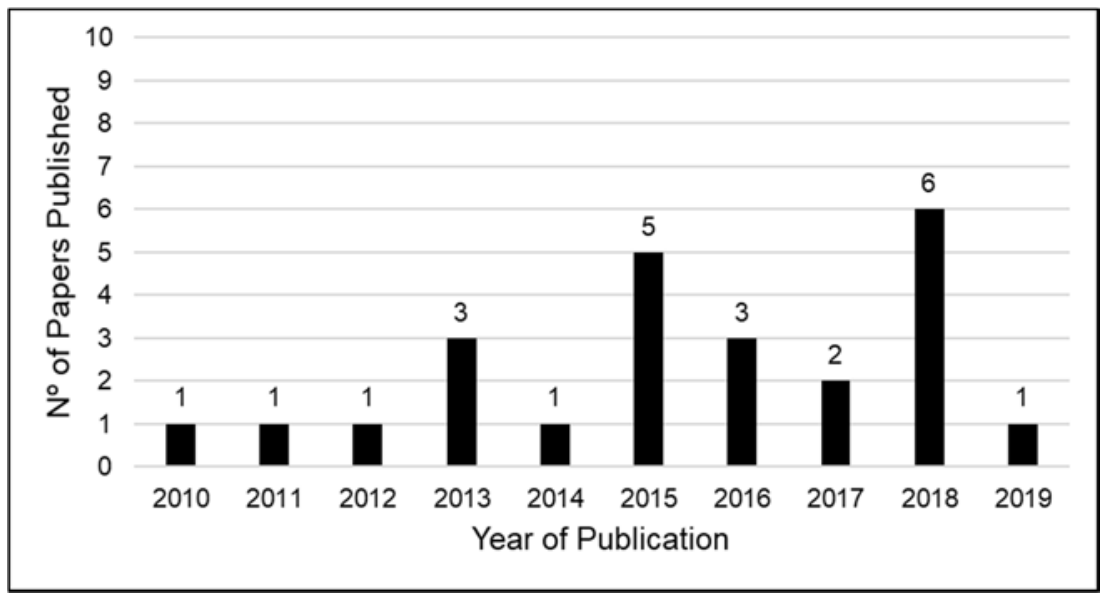

Figure 4: Number of publications per year

Source: Authors

In relation to the most cited authors within the selected publications, Małgorzata Jasiulewicz-Kaczmarek is present in 5 articles; Olivier Sénéchal and Benoit lung in 3 
INDEPENDENT JOURNAL OF MANAGEMENT \& PRODUCTION (IJM\&P)

http://Www.ijmp.jor.br

v. 10, n. 6, November-December 2019

ISSN: 2236-269X

DOI: 10.14807/ijmp.v10i6.939

articles; Anh Hoang, Farnaz G. Nezami, Marcos Macchi, Mehmet B. Yildirim and Phuc Do are authors that appeared in 2 publications; and the other authors are present in only one publication.

Other relevant information about the publications is related to the journals in which they were published. In this sense, all the selected journals were quantified, making it possible to show which journals are of major importance within the topics researched (Table 4).

It should be noted that the journal with the largest number of publications is the IFAC magazine, with 3 articles printed in its database Proceedings Volumes and 3 articles contained in its database PapersOnLine. The reason for the large number of publications is the fact that the magazine is focused on systems and controls, with one of the pillars of publication being the maintenance field.

Table 4: Publication number per journals

\begin{tabular}{|l|c|}
\hline \multicolumn{1}{|c|}{ Journals } & No of publications \\
\hline IFAC Proceedings Volumes & 3 \\
\hline IFAC PapersOnLine & 2 \\
\hline Industrial Engineering and Engineering Management & 2 \\
\hline Journal of Cleaner Production & 1 \\
\hline International Conference on Production Research & 1 \\
\hline International Journal of Industrial and Systems Engineering & 1 \\
\hline International Journal of Sustainable Engineering & 1 \\
\hline IOP Conference Series: Materials Science and Engineering & 1 \\
\hline Journal of Computational Science & 1 \\
\hline Journal of Manufacturing Science and Engineering & 1 \\
\hline Journal of Quality in Maintenance Engineering & 1 \\
\hline Journal of Risk and Reliability & 1 \\
\hline Mathematical Problems in Engineering & 1 \\
\hline Metalurgija & 1 \\
\hline Occupational Safety and Hygiene & 1 \\
\hline Procedia CIRP & 1 \\
\hline Proceedings of the European Safety and Reliability Conference & 1 \\
\hline Sustainable Systems and Technology & 1 \\
\hline
\end{tabular}

Source: Authors

The last feature analyzed was the quantification of the methodologies used in the research. Table 5 shows that the most used methodology was the mathematical modeling, adopted by 7 selected articles (29.0\%). 
DOI: 10.14807/ijmp.v10i6.939

Table 5: Methodologies used at the researches

\begin{tabular}{|c|c|c|}
\hline Methodology & Number of articles & $\%$ \\
\hline Mathematical modeling & 7 & 29.0 \\
\hline Theoretical-conceptual & 5 & 21.0 \\
\hline Survey & 5 & 21.0 \\
\hline Simulation & 4 & 16.5 \\
\hline Case study & 3 & 12.5 \\
\hline Total & 24 & $100 \%$ \\
\hline \multicolumn{2}{|c|}{ Source: Authors } \\
\hline
\end{tabular}

\subsection{Content Analysis}

The technique of content analysis seeks to analyze the information published by researches in a systematic, objective and reliable way (GUTHRIE et al., 2004). For this work, the content analysis sought to analyze how the concepts of sustainability are being inserted in the more addressed maintenance strategies at the literature and used in the industries.

For $\mathrm{CM}$, it is noted that selection and evaluation models involving the maintenance strategy consider only the economic criteria, with no emphasis on environmental and social factors. During the CM intervention, the costs associated with the lost production, labor force and spare parts are considered, which are classified as internal maintenance costs (RADHOUI et al., 2012; SARI et al., 2015; FRANCIOSI et al., 2017), as well as the environmental cost of carbon dioxide $\left(\mathrm{CO}_{2}\right)$ emissions during $\mathrm{CM}$, which is classified as an external cost of maintenance (FRANCIOSI et al., 2017). According to Jiang et al. (2018), the emphasis on the economic dimension is due to the high internal and external costs resulting from $\mathrm{CM}$ compared to other maintenance strategies.

With respect to $\mathrm{PM}$, some companies are considering criteria involving the three dimensions of sustainability when selecting and evaluating this maintenance strategy. For the economic dimension, the same internal and external maintenance costs used to select the CM are considered (RADHOUI et al., 2012; SARI et al., 2015; MACCHI et al., 2016; FRANCIOSI et al., 2017; JIANG et al., 2018; XIA et al., 2018).

For the environmental dimension, the consumption of electricity, the amount of GHG emitted and the waste generated before and after the PM are environmental criteria employed (YAN; HUA, 2010; NEZAMI; YILDIRAM, 2013; SANIUK et al., 2015; JIANG et al., 2018; XIA et al., 2018). For the social dimension, the criteria involve 
INDEPENDENT JOURNAL OF MANAGEMENT \& PRODUCTION (IJM\&P)

http://Www.ijmp.jor.br

v. 10, n. 6, November-December 2019

ISSN: 2236-269X

DOI: 10.14807/ijmp.v10i6.939

employee safety and health and stakeholder participation (NEZAMI; YILDIRIM, 2013; FRANCIOSI et al., 2017).

In the field of CBM, new optimization models are being developed with the aim of reducing the total costs of maintenance and the environmental impacts generated. In this regard, these models evaluate the energy consumption and $\mathrm{CO}_{2}$ emissions during the monitoring of the equipment, as well as the influence of the costs of these ecological factors along with other maintenance costs (HOANG et al., 2016; JIANG et al., 2018).

With respect to TPM, all costs involved in the production system are considered during the implementation of this maintenance strategy (NEZAMI; YILDIRIM, 2013; PIRES et al., 2015), in addition to the environmental and social criteria, such as: GHG emission, energy consumption, consumption of non-renewable resources, waste disposal (JASIULEWICZ-KACZMAREK, 2013b; JASIULEWICZ-KACZMAREK, 2014) and ergonomic issues (JASIULEWICZ-KACZMAREK, 2013a).

According to Saniuk et al. (2015) and Jasiulewicz-Kaczmarek (2015), for RCM to be applied in a production system, it is necessary to make use of a decision-making diagram to select which maintenance actions should be performed on the equipment according to the environmental consequences, operational and safety caused by each fault found. Therefore, it is indispensable to use economic, environmental and social criteria during the application of RCM.

When analyzing the 24 selected articles with the systematic literature review, it was noted that the concepts of sustainability are inserted in the maintenance strategies through economic, environmental and social indicators or criteria, which are fundamental for decision making made by specialists. Regarding the economic criteria, the most discussed in the studies are: cost associated with energy consumption, lost production cost, spare parts cost and cost associated with GHG emissions.

Pollutant emission due to energy consumption during machining/manufacturing is the most discussed environmental criteria. For the social criteria, the most mentioned in the publications is the health and safety at work. The full list of sustainability criteria addressed in the publications is shown in Table 6. 
INDEPENDENT JOURNAL OF MANAGEMENT \& PRODUCTION (IJM\&P)

http://Www.ijmp.jor.br

v. 10, n. 6, November-December 2019

ISSN: 2236-269X

DOI: 10.14807/ijmp.v10i6.939

Table 6: Sustainability criteria addressed in selected publications

\begin{tabular}{|c|c|c|c|}
\hline Dimension & Criteria & Authors & $\begin{array}{l}\text { Number of } \\
\text { Articles }\end{array}$ \\
\hline \multirow{5}{*}{ Economic } & $\begin{array}{l}\text { Cost associated with } \\
\text { energy consumption }\end{array}$ & $\begin{array}{l}\text { Hoang et al. (2016); Do et al. (2018); } \\
\text { Jiang et al. (2018); Xia et al. (2018); } \\
\text { Behzad et al. (2019) }\end{array}$ & 5 \\
\hline & Lost production cost & $\begin{array}{l}\text { Radhoui et al. (2012); Nezami and } \\
\text { Yildirim (2013); Franciosi et al. } \\
\text { (2017) }\end{array}$ & 3 \\
\hline & Spare parts cost & $\begin{array}{l}\text { Radhoui et al. (2012); Nezami and } \\
\text { Yildirim (2013); Sari et al. (2015) }\end{array}$ & 3 \\
\hline & $\begin{array}{l}\text { Cost associated with } \\
\text { GHG emissions }\end{array}$ & $\begin{array}{l}\text { Macchi et al. (2016); Franciosi et al. } \\
\text { (2017); Jiang et al. (2018) }\end{array}$ & 3 \\
\hline & Labor cost & $\begin{array}{c}\text { Radhoui et al. (2012); Sari et al. } \\
\text { (2015) }\end{array}$ & 2 \\
\hline \multirow[t]{3}{*}{ Environmental } & $\begin{array}{c}\text { Pollutant emission } \\
\text { due to energy } \\
\text { consumption during } \\
\text { machining/manufacturing }\end{array}$ & $\begin{array}{l}\text { Yan and Hua (2010); Nezami and } \\
\text { Yildirim (2013); Saniuk et al. (2015); } \\
\text { Sari et al. (2015); Amrina and } \\
\text { Aridharma (2016); Macchi et al. } \\
\text { (2016); Hoang et al. (2016); } \\
\text { Franciosi et al. (2017); Sénéchal } \\
\text { (2017); Do et al. (2018); Jiang et al. } \\
\text { (2018); Sénéchal (2018); Xia et al. } \\
\text { (2018); Behzad et al. (2019) }\end{array}$ & 14 \\
\hline & $\begin{array}{l}\text { Consumption of non- } \\
\text { renewable resources }\end{array}$ & $\begin{array}{l}\text { Nezami and Yildirim (2013); Saniuk } \\
\text { et al. (2015); Sari et al. (2015); } \\
\text { Amrina and Aridharma (2016); } \\
\text { Sénéchal (2017) }\end{array}$ & 5 \\
\hline & Waste disposal & $\begin{array}{l}\text { Nezami and Yildirim (2013); Saniuk } \\
\text { et al. (2015); Sari et al. (2015); } \\
\text { Sénéchal (2018) }\end{array}$ & 4 \\
\hline \multirow[t]{3}{*}{ Social } & $\begin{array}{l}\text { Health and safety at } \\
\text { work }\end{array}$ & $\begin{array}{l}\text { Nezami and Yildirim (2013); } \\
\text { Jasiulewicz-Kaczmarek (2013b); Sari } \\
\text { et al. (2015); Savino et al. (2015); } \\
\text { Amrina and Aridharma (2016); } \\
\text { Franciosi et al. (2017); Piechowski et } \\
\text { al. (2018) }\end{array}$ & 7 \\
\hline & Stakeholder participation & $\begin{array}{l}\text { Nezami and Yildirim (2013); Saniuk } \\
\text { et al. (2015); Sari et al. (2015) }\end{array}$ & 3 \\
\hline & Noise pollution & $\begin{array}{l}\text { Saniuk et al. (2015); Sari et al. } \\
\text { (2015) }\end{array}$ & 2 \\
\hline
\end{tabular}

Source: Authors

\subsection{Trends, Gaps and New Research Opportunities}

It was noted that the lack of studies and application of the concepts of sustainability by the industrial managers along with the maintenance strategies was due to the presumption that the reduction of environmental and social impacts increase the costs of maintenance actions, as mentioned by Nezami and Yildiran (2013). 
INDEPENDENT JOURNAL OF MANAGEMENT \& PRODUCTION (IJM\&P)

http://Www.ijmp.jor.br

v. 10, n. 6, November - December 2019

ISSN: 2236-269X

DOI: 10.14807/ijmp.v10i6.939

However, in the last few years, some articles have been deepened in the assumption raised and noted that the inclusion of the sustainability criteria in the maintenance actions helps: in the optimization of the preventive stops, in the control of the use of raw material during the production, in the control of consumption of electricity and of lubricating oil by the equipment and reduction of the impacts in the sustainability. By way of example, Franciosi et al. (2017) noted that food companies considering the environmental and social costs during PM planning achieved a reduction of up to $5 \%$ in total maintenance costs.

In addition, Saniuk et al. (2015), through in-depth research with companies in the foundry field that use sustainable criteria in the maintenance area, obtained: $20 \%$ savings in the use of raw material during production, $15 \%$ reduction in the consumption of electricity by equipment, $20 \%$ longer service life of lubricating oils and reduction of noise and emissions of pollutants by the machines.

The use of methods or tools enabling successful management of the maintenance strategies can be crucial for the maintenance actions efficiency and mitigation of their sustainability impacts. This case can be exemplified through the use of Failure Mode and Effect Analysis (FMEA) method in PM. According to Piechowski et al. (2018), this combination reduces or eliminates the causes of failures, taking into account the effects of failures on safety of operators and process as well as threats to the environment.

Others researches are developing methods that use sustainability criteria to achieve maximum productive capacity and equipment availability at the lowest possible cost, with emphasis on productive systems that adopt PM or CBM (YAN; HUA, 2010; RADHOUI et al., 2012; SANIUK et al., 2015; HOANG et al., 2016; FRANCIOSI et al., 2017; JIANG et al., 2018).

Currently, CBM is being used more frequently by companies to minimize economic losses by unexpected interruptions of equipment, reduce energy consumption during production and provide a safe working environment for employees. These benefits are verified by Do et al. (2018) through a case study on the TELMA platform, software dedicated to the electronic maintenance of a real industry, and by Behzad et al. (2019) through the use of CBM in a central boiler room, revealing a saving of $591312 \mathrm{kWh}$ in gas consumption and 151795 liters in water 
consumption, which equals a saving of 2330 US dollars in resource consumption and 35400 US dollars in maintenance cost.

In order to make condition monitoring and prediction information more precise and, consequently, to achieve a more sustainable system, the use of Cyber Physical Systems and Big Data (Industry 4.0 technologies) has been used with CBM. According to Sénéchal (2018) and Kumar et al. (2018), Industry 4.0 tools are important for the acquisition and management of data obtained during maintenance actions and for the formation of sustainability indicators.

Most methods developed use data from the literature to quantify the environmental and social impacts resulting from the evaluated maintenance actions, generating doubts as to whether the impacts evaluated are in line with the actual situation of the cases studied.

Another identified gap concerns the difficulty in evaluating the social impacts resulting from maintenance actions and, consequently, using social data as an aid in the planning of maintenance strategies in a company. According to Franciosi et al. (2017), costs incurred for the health, safety and well-being of employees and society interfere with the total cost of maintenance.

Given the gaps presented, future research may:

- Develop methods that use technological tools to collect and store data on the environmental and social impacts of industrial maintenance in the evaluated companies, such as the electronic platforms TELMA, PROTEUS and CASIP, and the technologies of Industry 4.0, such as Big Data, Internet of Things and Cyber Physical Systems;

- Conduct case studies that quantitatively establish the importance of considering social criteria during the planning of maintenance strategies.

\section{FINAL CONSIDERATIONS}

Maintenance has long been recognized as an activity responsible for optimizing the availability of equipment at the lowest possible cost. From a strategic perspective, maintenance also has the responsibility to reduce environmental impacts and help social well-being. However, few companies adopt the sustainable maintenance because they ignore the subject and its benefits. In addition, there are few articles on 
integrating sustainability into maintenance activities, which contributes to its lack of dissemination. This article aimed to show how sustainability concepts are being inserted in the maintenance strategies aiming to contribute to the dissemination of the theme and motivate the companies to implement sustainable maintenance.

In order to reach the objective, a systematic literature review was carried out and twenty-four most representative publications on the subject were identified. The bibliometric analysis showed that the publications involving the insertion of sustainability concepts in the maintenance strategies occurred between 2010 and 2019, with more publications in 2018.

The research found that sustainability concepts are integrated into maintenance strategies through economic, environmental and social criteria, which are fundamental for decision making made by specialists. As for the economic criteria, the most discussed in the studies are: cost associated with energy consumption, lost production cost, spare parts cost and cost associated with GHG emissions. For the environmental criteria, the most discussed in the selected publications is the pollutant emission due to energy consumption during machining/manufacturing. Regarding the social criteria, the health and safety at work is the most approached.

The study also identified that there is a trend in the development of methods using sustainability criteria to achieve maximum productive capacity and equipment availability at the lowest possible cost, with emphasis on productive systems that adopt PM or CBM. However, most methods developed do not use data on the impacts of industrial maintenance on sustainability to plan the maintenance strategies and also do not emphasize the social impacts. Based on these assumptions, the authors suggest the development of new methods that fill these identified gaps, using technological tools to collect and store data the sustainability impacts of maintenance, such as the electronic platforms TELMA, PROTEUS and CASIP, and the technologies of Industry 4.0, such as Big Data, Internet of Things and Cyber Physical Systems.

The results and conclusions presented are limited to the selected databases (Science Direct, Scopus and Web of Science), and it is necessary to extend the current research through other bases. However, although there is a limitation, the findings presented in this article contribute to the development of the field of knowledge and 
INDEPENDENT JOURNAL OF MANAGEMENT \& PRODUCTION (IJM\&P)

http://Www.ijmp.jor.br

v. 10, n. 6, November-December 2019

ISSN: 2236-269X

DOI: 10.14807/ijmp.v10i6.939

can serve as inspiration for the development of new studies, both for academics and professionals in the maintenance and sustainability areas of the industry.

\section{REFERENCES}

AL-NAJJAR, B.; ASYOUF, I. (2003) Selecting the most efficient maintenance approach using fuzzy multiple criteria decision making. International Journal of Production Economics, v. 84, n. 1, p. 85-100. DOI: https://doi.org/10.1016/S09255273(02)00380-8.

AMRINA, E.; ARIDHARMA, D. (2016) Sustainable maintenance performance evaluation model for cement industry. Industrial Engineering and Engineering Management (IEEM), p. 350-354. DOI: 10.1109/IEEM.2016.7797895.

ASHLEY, P. A. (2005) Ética e responsabilidade social nos negócios. São Paulo: Saraiva.

BEHZAD, M.; KIM, H.; BEHZAD, M.; BEHAMBARI, H. A. (2019) Improving sustainability performance of heating facilities in a central boiler room by conditionbased maintenance. Journal of Cleaner Production, v. 206, p. 713-723. DOI: https://doi.org/10.1016/j.jclepro.2018.09.221.

BRUNDTLAND, G. H. (1987) Our common future-Call for action. Environmental Conservation, v. 14, n. 4, p. 291-294. DOI:

https://doi.org/10.1017/S0376892900016805.

CHITRA, T. (2003) Life based maintenance policy for minimum cost. Reliability and Maintainability Symposium (IEEE), p. 470-474. DOI:

10.1109/RAMS.2003.1182034.

DIMITROFF-REGATSCHNIG, H.; SCHNITZER, H. (1998) A techno-economic approach to link waste minimization technologies with the reduction of corporate environmental costs: effects on the resource and energy efficiency of production. Journal of Cleaner Production, v. 6, n. 3-4, p. 213-225. DOI: https://doi.org/10.1016/S0959-6526(98)00004-3.

DO, P.; HOANG, A.; IUNG, B.; VU, H. C. (2018) Energy efficiency for conditionbased maintenance decision-making: Application to a manufacturing platform. Proceedings of the Institution of Mechanical Engineers, Part O: Journal of Risk and Reliability, v. 232, n. 4, p. 379-388. DOI: https://doi.org/10.1177/1748006X18762282.

ELKINGTON, J. (1998) Accounting for the triple bottom line. Measuring Business Excellence, v. 2, n. 3, p. 18-22. DOI: https://doi.org/10.1108/eb025539.

FRANCIOSI, C.; LAMBIASE, A.; MIRANDA, S. (2017) Sustainable Maintenance: A Periodic Preventive Maintenance Model with Sustainable Spare Parts Management. IFAC-Papers OnLine, v. 50, n. 1, p. 13692-13697. DOI: https://doi.org/10.1016/j.ifacol.2017.08.2536.

GANDHARE, B. S.; AKARTE, M. (2012) Maintenance strategy selection. Ninth AIMS International Conference on Management, p. 1330-1336.

GRALL, A.; DIEULLE, L.; BÉRENGUER, C.; ROUSSIGNOL, M. (2002) Continuoustime predictive-maintenance scheduling for a deteriorating system. IEEE

Transactions on Reliability, v. 51, n. 2, p. 141-150. DOI: 
INDEPENDENT JOURNAL OF MANAGEMENT \& PRODUCTION (IJM\&P)

http://www.ijmp.jor.br

v. 10, n. 6, November - December 2019

ISSN: 2236-269X

DOI: 10.14807/ijmp.v10i6.939

10.1109/TR.2002.1011518.

GUDMUNDSSON, H.; HALL, R. P.; MARSDEN, G.; ZIETSMAN, J. (2015)

Sustainable transportation: Indicators, frameworks, and performance management. Springer.

GUTHRIE, J.; PETTY, R.; YONGVANICH, K.; RICCERI, F. (2004) Using content analysis as a research method to inquire into intellectual capital reporting. Journal of Intellectual Capital, v. 5, n. 2, p. 282-293. DOI:

https://doi.org/10.1108/14691930410533704.

GUTOWSKI, T.; MURPHY, C.; ALLEN, D.; BAUER, D.; BRAS, B.; PIWONKA, T.; SHENG, P.; SUTHERLAND, J.; THURSTON, D.; WOLFF, E. (2005) Environmentally benign manufacturing: observations from Japan, Europe and the United

States. Journal of Cleaner Production, v. 13, n. 1, p. 1-17. DOI:

https://doi.org/10.1016/j.jclepro.2003.10.004.

HENNEQUIN, S.; RESTREPO, L. M. R. (2016) Fuzzy model of a joint maintenance and production control under sustainability constraints. IFAC-PapersOnLine, v. 49, n. 12, p. 1216-1221. DOI: https://doi.org/10.1016/j.ifacol.2016.07.676.

HOANG, A.; DO, P.; IUNG, B. (2016) Investigation on the use of energy efficiency for condition-based maintenance decision-making. IFAC-PapersOnLine, v. 49, n. 28, p. 73-78. DOI: https://doi.org/10.1016/j.ifacol.2016.11.013.

IGHRAVWE, D. E.; IGHRAVWE, D. E.; AYOOLA OKE, S.; AYOOLA OKE, S. (2017) Ranking maintenance strategies for sustainable maintenance plan in manufacturing systems using fuzzy axiomatic design principle and fuzzy-TOPSIS. Journal of Manufacturing Technology Management, v. 28, n. 7, p. 961-992. DOI: https://doi.org/10.1108/JMTM-01-2017-0007.

IUNG, B.; LEVRAT, E. (2014) Advanced maintenance services for promoting sustainability. Procedia CIRP, v. 22, p. 15-22. DOI:

https://doi.org/10.1016/j.procir.2014.07.018.

JAMALI, D. (2006) Insights into triple bottom line integration from a learning organization perspective. Business Process Management Journal, v. 12, n. 6, p. 809-821. DOI: https://doi.org/10.1108/14637150610710945.

JASIULEWICZ-KACZMAREK, M. (2013a) The role and contribution of maintenance in sustainable manufacturing. IFAC Proceedings Volumes, v. 46, n. 9, p. 11461151. DOI: https://doi.org/10.3182/20130619-3-RU-3018.00511.

JASIULEWICZ-KACZMAREK, M.; BAPTISTA, J. S.; BARROSO, M.; CARNEIRO, P.; LAMB, P.; COSTA, N.; PERESTRELO, G. (2013b) The role of ergonomics in implementation of the social aspect of sustainability, illustrated with the example of maintenance. Occupational Safety and Hygiene, p. 47-52.

JASIULEWICZ-KACZMAREK, M. (2014) Integrating lean and green paradigms in maintenance management. IFAC Proceedings Volumes, v. 47, n. 3, p. 4471-4476. DOI:_https://doi.org/10.3182/20140824-6-ZA-1003.02213.

JASIULEWICZ-KACZMAREK, M. (2015) Practical aspects of the application of RCM to select optimal maintenance policy of the production line. Safety and Reliability:

Methodology and Applications-Proceedings of the European Safety and Reliability Conference (ESREL), p. 1187-1195. 
INDEPENDENT JOURNAL OF MANAGEMENT \& PRODUCTION (IJM\&P)

http://Www.ijmp.jor.br

v. 10, n. 6, November-December 2019

ISSN: 2236-269X

DOI: 10.14807/ijmp.v10i6.939

JAYAL, A. D.; BADURDEEN, F.; DILLON, O. W.; JAWAHIR, I. S. (2010) Sustainable manufacturing: Modeling and optimization challenges at the product, process and system levels. CIRP Journal of Manufacturing Science and Technology, v. 2, n. 3, p. 144-152. DOI:_https://doi.org/10.1016/j.cirpj.2010.03.006.

JIANG, A.; DONG, N.; TAM, K. L.; LYU, C. (2018) Development and Optimization of a Condition-Based Maintenance Policy with Sustainability Requirements for Production System. Mathematical Problems in Engineering. DOI: https://doi.org/10.1155/2018/4187575.

KELLY, A. (1997) Maintenance strategy business-centred maintenance. Elseveir and Butterworth Heinemann, New York, NY.

KHAN, F. I.; HADDARA, M. M. (2003) Risk-based maintenance (RBM): a quantitative approach for maintenance/inspection scheduling and planning. Journal of Loss Prevention in the Process Industries, v. 16, n. 6, p. 561-573. DOI: https://doi.org/10.1016/j.jp.2003.08.011.

KUMAR, A.; SHANKAR, R.; THAKUR, L. S. (2018) A big data driven sustainable manufacturing framework for condition-based maintenance prediction. Journal of Computational Science, v. 27, p. 428-439. DOI:

https://doi.org/10.1016/j.jocs.2017.06.006

LEVY, Y.; ELLIS, T. J. (2006) A systems approach to conduct an effective literature review in support of information systems research. Informing Science, v. 9, p. 181212. DOI: https://doi.org/10.28945/479.

MACCHI, M.; FARRUKU, K.; HOLGADO, M.; NEGRI, E.; PANARESE, D. (2016) Economic and environmental impact assessment through system dynamics of technology-enhanced maintenance services. International Journal of Industrial and Systems Engineering, v. 23, n. 1, p. 36-56. DOI:

https://doi.org/10.1504/IJISE.2016.075806.

MARQUEZ, A. C.; GUPTA, J. N. (2006) Contemporary maintenance management: process, framework and supporting pillars. Omega, v. 34, n. 3, p. 313-326. DOI: https://doi.org/10.1016/j.omega.2004.11.003.

MOUBRAY, J. (2000) The case against streamlined RCM. Aladon, UK.

NAMBIAR, A. N. (2010) Challenges in sustainable manufacturing. Proceedings of the 2010 International Conference on Industrial Engineering and Operations Management. Dhaka, Bangladesh, p. 1-6.

NEZAMI, F. G.; YILDIRIM, M. B. (2011) A framework for a fuzzy sustainable maintenance strategy selection problem. Sustainable Systems and Technology (ISSST), p. 1-1. DOI: 10.1109/ISSST.2011.5936857.

NEZAMI, F. G.; YILDIRIM, M. B. (2013) A sustainability approach for selecting maintenance strategy. International Journal of Sustainable Engineering, v. 6, n. 4, p. 332-343. DOI: https://doi.org/10.1080/19397038.2013.765928.

O'CONNOR, M.; SPASH, C. (1999) Valuation and the Environment: Theory, Method and Practice. Northampton (MA): Edward Elgar.

PARKIN, S. (2000) Sustainable development: the concept and the practical challenge. Proceedings of the Institution of Civil Engineers-Civil Engineering, Thomas Telford Ltd., vol. 138, n. 6, p. 3-8. DOI: 
INDEPENDENT JOURNAL OF MANAGEMENT \& PRODUCTION (IJM\&P)

http://Www.ijmp.jor.br

v. 10, n. 6, November-December 2019

ISSN: 2236-269X

DOI: 10.14807/ijmp.v10i6.939

https://doi.org/10.1680/cien.2000.138.6.3.

PIECHOWSKI, M.; SZAFER, P.; WYCZOLKOWSKI, R.; GLADYSIAK, V. (2018) Concept of the FMEA method-based model supporting proactive and preventive maintenance activities. IOP Conference Series: Materials Science and Engineering. IOP Publishing, p. 1-13.

PINJALA, K.S. (2008) Dynamics of Maintenance Strategy. Katholieke Universiteit Leuven. Belgium. Doctoral Report.

PIRES, S. P.; SÉNÉCHAL, O; DESCHAMPS, F.; LOURES, E.F.R.; PERRONI, M.G. (2015) Industrial maintenance for sustainable performance: a systematic literature review. International Conference on Production Research, p. 1-14.

PUSAVEC, F.; KRAJNIK, P.; KOPAC, J. (2010) Transitioning to sustainable production-Part I: application on machining technologies. Journal of Cleaner Production, v. 18, n. 2, p. 174-184. DOI:

https://doi.org/10.1016/j.jclepro.2009.08.010.

RADHOUI, M.; TLILI, L.; CHELBI, A.; REZG, N. (2012) Preventive maintenance policy for multi-component systems subject to random environmental damage generation. IFAC Proceedings Volumes, v. 45, n. 31, p. 109-114. DOI: https://doi.org/10.3182/20121122-2-ES-4026.00026.

SANIUK, A.; JASIULEWICZ-KACZMAREK, M.; SAMOLEJOVÁ, A.; SANIUK, S.; LENORT, R. (2015) Environmental favourable foundries through maintenance activities. Metalurgija, v. 54, n. 4, p. 725-728.

SARI, E.; SHAHAROUN, A. M.; MA'ARAM, A.; YAZID, A. M. (2015) Sustainable maintenance performance measures: a pilot survey in Malaysian automotive companies. Procedia CIRP, v. 26, p. 443-448. DOI:

https://doi.org/10.1016/j.procir.2014.07.163.

SAVINO, M. M.; MACCHI, M.; MAZZA, A. (2015) Investigating the impact of social sustainability within maintenance operations: An action research in heavy industry. Journal of Quality in Maintenance Engineering, v. 21, n. 3, p. 310-331. DOI: https://doi.org/10.1108/JQME-06-2014-0038.

SÉNÉCHAL, O. (2017) Research directions for integrating the triple bottom line in maintenance dashboards. Journal of Cleaner Production, v. 142, p. 331-342. DOI: https://doi.org/10.1016/j.jclepro.2016.07.132.

SÉNÉCHAL, O. (2018) Performance indicators nomenclatures for decision making in sustainable conditions based maintenance. IFAC-PapersOnLine, v. 51, n. 11, p. 1137-1142. DOI: https://doi.org/10.1016/j.ifacol.2018.08.438.

SHARMA, R. K.; KUMAR, D.; KUMAR, P. (2005) FLM to select suitable maintenance strategy in process industries using MISO model. Journal of Quality in Maintenance Engineering, v. 11, n. 4, p. 359-374. DOI: https://doi.org/10.1108/13552510510626981.

WANG, L.; CHU, J.; WU, J. (2007) Selection of optimum maintenance strategies based on a fuzzy analytic hierarchy process. International Journal of Production Economics, v. 107, n. 1, p. 151-163. DOI: https://doi.org/10.1016/j.ijpe.2006.08.005.

WILLMOTT, P.; MCCARTHY, D. (2000) TPM-A Route to World Class

Performance: A Route to World Class Performance. Elsevier. 
WIREMAN, T. (1990) World class maintenance management. New York, NY: Industrial Press.

XIA, T.; XI, L.; DU, S.; XIAO, L.; PAN, E. (2018) Energy-Oriented Maintenance Decision-Making for Sustainable Manufacturing Based on Energy Saving Window. Journal of Manufacturing Science and Engineering, v. 140, n. 5, p.1-12. DOI:10.1115/1.4038996.

YAN, J.; HUA, D. (2010) Energy consumption modeling for machine tools after preventive maintenance. Industrial Engineering and Engineering Management (IEEM), p. 2201-2205.

ZHANG, Q. (2013) Case study of cost benefits of condition based maintenance used in medical devices. Reliability and Maintainability Symposium (RAMS), 2013 Proceedings-Annual, p. 1-5. DOI: 10.1109/RAMS.2013.6517676. 